\title{
The Impact of Rural Population Aging on Farmers' Cleaner Production Behavior: Evidence from Five Provinces of the North China Plain
}

\author{
Jing Liu ${ }^{1, *}$, Shichun $\mathrm{Du}^{2}{ }^{-1}$ and Zetian $\mathrm{Fu}^{3}$ \\ 1 School of Business, Ludong University, Yantai 264025, China \\ 2 School of Public Administration, Shandong Technology and Business University, Yantai 264005, China; \\ dschcau@sdtbu.edu.cn \\ 3 Yantai Research Institute, China Agricultural University, Yantai 264670, China; fzt@cau.edu.cn \\ * Correspondence: jliu@ldu.edu.cn
}

check for updates

Citation: Liu, J.; Du, S.; Fu, Z. The Impact of Rural Population Aging on Farmers' Cleaner Production Behavior: Evidence from Five Provinces of the North China Plain. Sustainability 2021, 13, 12199. https:/ / doi.org/10.3390/su132112199

Academic Editor: Ermanno C. Tortia

Received: 3 October 2021

Accepted: 4 November 2021

Published: 5 November 2021

Publisher's Note: MDPI stays neutral with regard to jurisdictional claims in published maps and institutional affiliations.

Copyright: (c) 2021 by the authors. Licensee MDPI, Basel, Switzerland. This article is an open access article distributed under the terms and conditions of the Creative Commons Attribution (CC BY) license (https:// creativecommons.org/licenses/by/ $4.0 /)$.

\begin{abstract}
The purpose of this article is to examine the impact of rural population aging on farmers' cleaner production behavior through the intervening effects of three aspects (learning capacity, factor substitution and behavior imitation). The data used in this article were collected from a questionnaire survey of 916 farmers in the main grain producing provinces of the North China Plain. First, confirmatory factor analysis was carried out, and then data were analyzed through structural equation modeling using the bootstrap methodology in AMOS 24. The findings indicate that rural population aging inhibits farmers' cleaner production behavior through learning capacity. In contrast, rural population aging promotes farmers' cleaner production behavior through factor substitution and behavior imitation. From the perspective of both challenges and opportunities, this article investigates the impact mechanism and comprehensive effect of rural population aging on farmers' cleaner production behavior, so as to explore new ways to promote cleaner agricultural production under the background of an accelerated aging the of rural labor force and provide reference for the formulation of relevant policies.
\end{abstract}

Keywords: rural population aging; cleaner agricultural production; learning capacity; factor substitution; behavior imitation

\section{Introduction}

For a long time, China has relied on an agricultural production mode for the highintensity development of its resources as well as a high concentration of production factors, resulting in environmental pollution and low resource utilization efficiency, which restricts the sustainable development of agriculture and the rural economy [1]. At present, China has less than $8 \%$ of the world's arable land, but its use of chemical fertilizer accounts for $35 \%$ of the global total, which is equivalent to the sum usage of the United States and India [2]. The pesticide utilization rate is only 35\%, 10-20 percentage points lower than that in developed countries [2]. China's agricultural water consumption accounts for more than $60 \%$ of national economic water consumption, and agricultural irrigation water efficiency is only $75 \%$ of developed countries [3]. On the whole, the marginal benefit of China's agricultural inputs has decreased significantly, and the environmental capacity is approaching its limit [4]. The old agricultural development model has seriously affected the sustainable development of China's agriculture [5].

Cleaner agricultural production can meet the needs of agricultural sustainable development by using clean energy and raw materials, improving the regulatory system and reducing all kinds of pollution in the process of agricultural product [6-8]. Cleaner production has different names in different development stages or different countries, such as "waste reduction", "waste free process", "pollution prevention", etc. But its basic connotation is the same, that is to take pollution prevention strategies for products 
and product production processes to reduce the generation of pollutants [7]. Cleaner agricultural production is a practical agricultural technology and scientific production management mode, which can not only meet the needs of agricultural production, but also make rational use of resources and protect the environment. For example, by strictly controlling the total amount of agricultural water, reducing the use of chemical fertilizers and pesticides, and recycling livestock manure, crop straw, agricultural film and other agricultural wastes [4]. Its essence is to produce and use environment-friendly "green" agricultural inputs in the whole process of agricultural production, control agricultural pollution from the source, reduce the risk of agricultural production and service process to environment and human beings, realize the sustainable unity of social, economic and ecological benefits, and promote the sustainable development of agriculture.

Since the release of China's cleaner production action plan (draft) in 1992, China has successively formulated and promulgated a series of rules and regulations on cleaner agricultural production. The Ministry of Agriculture and Rural Affairs of the People's Republic of China issued the "Opinions on Promoting Agricultural Cleaner Production" in 2011. Over the years, "Document No.1 of the Central Government" also emphasized the promotion of cleaner agricultural production several times. However, government participation is not enough to solve the problem, because farmers are the decision-makers and executors of agricultural production. With the continuous advancement of urbanization and industrialization in China, a large number of rural labor force transferred to urban and non-agricultural sectors, the age structure of agricultural population has changed significantly, the burden of agricultural production has shifted from a young labor force to an aging labor force, and the aging trend of rural labor force in China is obvious.

Aging is a dynamic growth of the proportion of the elderly population in the total population due to a decrease in the number of young people and an increase in the number of elderly people. Generally speaking, when the elderly population over 60 years old accounts for $10 \%$ of the total population in a country or region, or the elderly population over 65 years old accounts for $7 \%$ of the total population, it means that the country or region is an aging society [9]. In 2000, the proportion of the rural population over 65 years old accounted for only 7.35\% of the rural population in China. In 2016, the proportion rose to $12.53 \%$ [10]. According to the data for China's Seventh National Census in 2021, the proportion of the elderly aged 60,65 or higher in rural China is $23.81 \%$ and $17.72 \%$ respectively, 7.99 and 6.61 percentage points higher than in urban areas. Therefore, we need to pay attention to the aging of the rural population in China, and analyze its impact and mechanism on farmers' cleaner agricultural production behavior.

The contribution of this article is that we pay attention to the remarkable feature of the accelerated aging of China's rural labor force, analyze its impact on farmers' cleaner production behavior and the corresponding mechanism, and answer the question of how to promote cleaner agricultural production under the background of labor aging, which is of great significance for realizing agricultural green development and ensuring food security.

This rest of this article is organized as follows. Section 2 conducts a literature review. Section 3 presents the theory and hypotheses. Section 4 describes data sources and methodology. Section 5 analyses the empirical results. Section 6 provides the main findings and policy recommendations.

\section{Literature Review}

\subsection{Aging of Rural Population}

After the Second World War, due to the continuous improvement of human living conditions, the global average life expectancy increased from 46.5 years in the early $1950 \mathrm{~s}$ to 71.4 years in 2015 [11,12]. Over the same period, the global total fertility rate fell from 5.0 to 2.5 [13]. Under the "dual" effect of prolonging life expectancy and declining fertility rate, the proportion of people aged 65 and over in the world's total population has increased from less than 5\% to $8.5 \%[12,13]$. Population aging has become a global social and economic development problem and presents an accelerated development trend with 
the passage of time [14]. According to the research results of the U.S. Census Bureau, by 2050, the proportion of the global population aged 65 and over will further rise to $16.7 \%$, with a total scale of 1.566 billion, of which developing countries will have the largest and fastest growth, and their elderly population will quadruple on the basis of the beginning of the 21 st century $[13,15]$.The increasingly severe aging situation will have a far-reaching impact on economy, society, culture and politics in all aspects, and become a great challenge for global sustainable development.

The research on population aging originated from Britain, France, and other leading industrialized countries in Western Europe [16]. By the 1970s, with the increasingly prominent problem of population aging in newly industrialized and developing countries, the contents and methods of aging research were continuously expanded and deepened. On the whole, these studies mainly focus on demography, sociology, management, biology, medicine, etc., involving the impact of population aging on social and economic development [17-19], construction of social security systems for the elderly [20], development and utilization of human resources for the elderly [21], development and evolutionary trends of aging [22,23], and countermeasures for population aging [24].

Since the founding of new China, great changes have taken place in China's rural population structure [25]. China's rural labor force and corresponding agricultural production system have experienced four evolution stages: In the first stage, from the founding of new China to 1978, a unified planned production and universal planned rationing system were implemented, forming a household registration migration system that strictly restricted the flow of rural population to cities. Under the collective ownership of the people's commune, it is almost impossible for farmers to control their own labor production factors. The rural labor force is confined to the land, resulting in serious loss of production efficiency and forming a "poverty trap". In the second stage, from 1978 to 1984, the high-efficiency inputs of the rural labor force led to an ultra-high growth of agriculture. The household contract system replaced the inefficient production team management system, which fundamentally changed the incentive mechanism of agricultural production and greatly improved the marginal output of agriculture. At the same time, the restrictive policy of rural labor mobility began to loosen. In the third stage, from 1985 to 2000, the "double track" management of grain and the outflow of rural labor force started. The contract ordering system of grain production replaced the unified purchase and marketing system of grain, which made it possible for the rural surplus labor force to be separated from grain production. A "tide of migrant workers" began to appear, and the employment management system for the cross regional mobility of the rural labor force was implemented. The fourth stage, since 2001, has been marked by an implementation of the marketization of the purchase and sale of agricultural products which has accelerated the outflow of the rural labor force. The market-oriented reform of the grain circulation system has greatly reduced the direct restrictions on the flow of rural labor and accelerated its outflow. The outflow of the rural labor force is not only the process of reallocation of family labor resources, but also a new contractual arrangement among family members. More and more young adults choose to leave the countryside to engage in non-agricultural operations, resulting in the decline of the level of human capital invested in agricultural production and the aging of agricultural producers.

\subsection{Impact of Aging on Agricultural Production}

First, the impact of aging on the input of agricultural production factors. Some scholars have found that due to the limitation of their own physical energy, aging farmers tend to abandon their land, reduce labor input to agricultural production and reduce land use rate, resulting in insufficient agricultural labor and land input, which has a negative impact on agricultural output $[26,27]$. In addition, some scholars believe that although elderly farmers are not good at directly adopting modern agricultural technology and production modes due to their low level of education, conservative ideas and poor ability to accept new things, they will replace the labor force by purchasing "outsourcing" services 
of agricultural machinery and "capital" means of production such as chemical fertilizer, pesticide and thin film. Therefore, the view that the aging of the agricultural labor force has a significant negative impact on the investment of land factors is debatable [28,29].

Secondly, the impact of aging on agricultural production efficiency. In the short term, the aging of the agricultural labor force has no significant negative impact on agricultural production [30], but in the long term, it has a significant negative effect [31]. Rural mechanization and infrastructure investment can offset part of the negative impact [32] to a certain extent. The aging of the agricultural labor force has a significant negative impact on the comprehensive technical efficiency and pure technical efficiency of farmers. From different regions, the aging of the labor force reduces farmers' technical efficiency of agricultural production in northern China, but the impact on farmers in southern China is not significant [33].

Thirdly, the impact of aging on farmers' behavior decision-making. In terms of planting structure, due to the suitability of mechanical farming in plain areas, elderly farmers will increase the planting proportion of grain crops with a high degree of mechanization. In Hilly and mountainous areas, agricultural machinery is difficult to replace labor, and elderly farmers will increase the planting proportion of cash crops with high economic benefits [34]. Zhang R.J. found that the aging of the agricultural labor force has a significant positive impact on land transfer [35].

To sum up, does the aging of the rural population affect farmers' cleaner production behavior? If so, what is the mechanism? Scholars have little research on this issue. The formation of the concept of cleaner agricultural production and the application of cleaner production technology largely depend on the level of human capital in the rural labor force. Knowledge, skills, health, and the physical strength of the rural labor force are the main content of human capital. Schultz believes that human capital plays an important role in the process of agricultural technology progress and traditional agricultural transformation [36]. However, according to the life cycle theory of human capital stock, with the increase of age, the stock of human capital increases, and then gradually decreases after reaching the peak [37]. This means that the aging of the rural population will inevitably lead to the weakening of agricultural human capital. Compared with the young and middle-aged labor force, the aging population has rich experience, but knowledge system is relatively old, and it is weak in cognitive ability and the ability to learn new technology, thus hindering the application of cleaner production technology in agricultural production [38]. However, some scholars believe that aging does not necessarily hinder the development of cleaner agricultural production, because some external conditions can effectively improve the human capital constraints of an aging labor force [39,40]. For example, the perfecting of an outsourcing service level, the improvement of rural public goods supply and collective decision-making can effectively reduce the adverse impact of aging on cleaner agricultural production. Population aging reduces the number of farmers and forces the upgrading of agricultural technology [41]. This means that the traditional mode of agricultural production which has been dependent on labor input may be broken due to the application and promotion of advanced science and technology. From this perspective, population aging provides a chance for the development of cleaner agricultural production, but there is little literature that has carried out in-depth analysis on it.

Based on the survey data of farmers in five provinces of the North China Plain, this paper uses a structural equation model and intermediary effect test method to study the impact of rural population aging on farmers' cleaner production behavior, so as to explore new ways to promote China's cleaner agricultural production under the background of agricultural population aging, and provide reference for the formulation of government policies. 


\section{Theory and Hypotheses}

\subsection{Human Capital Theory}

In the 1960s, American economists Schultz and Becker founded the human capital theory. Human capital is an intangible asset, which includes knowledge, skills, health and so on $[36,42]$. The role of human capital is greater than that of material capital. Therefore, human capital, as the power source of the transformation of agricultural production from traditional to modern, determines the promotion of agricultural clean technology. Human capital follows the law of life cycle, and there is an inverted U-shaped relationship between age and human capital stock of the agricultural labor force [43,44]. The age effect of elderly farmers is obvious, the learning ability and innovation consciousness decrease with the increase of age, and the efficiency of the human capital mechanism is generally not high, which is an important obstacle to the promotion of agricultural clean technology [45]. Learning ability refers to the ability of a labor force to acquire, identify, transform and utilize knowledge [46,47]. Compared with young farmers, old farmers' physical and mental functions are weakened, their ability to accept new things is poor, and their ability to obtain, identify, transform and utilize clean technologies is relatively low. This means that with the growth of age, the learning ability of the rural elderly labor force will decline, which will directly affect the willingness to adopt clean technology, and even hinder the promotion and application of clean technology for the sake of their own vested interests.

Based on the above analysis, this article puts forward Hypothesis 1 (H1):

Hypothesis 1 (H1). Rural population aging has a negative impact on farmers' cleaner production behavior through learning capacity.

\subsection{Labor Supply Theory}

According to the labor supply theory, workers, as "rational people", determine their labor supply time according to the principle of utility maximization under existing budget constraints. When budget constraints change due to changes in economic parameters, workers constantly adjust their labor supply by maximizing utility [48]. Many links of cleaner production are continuous operations with high technical content. It is difficult for an elderly labor force to be competent by relying on their own ability. Acemoglu believes that when labor resources are relatively scarce, replacing labor with technology can save production costs [49]. When elderly farmers are constrained by labor supply, they will reconfigure production factors and replace labor input through capital investment and energy-saving technology [50]. Therefore, they often purchase some agricultural socialized services related to cleaner production, such as straw returning services, soil testing and formulated fertilization services, green technology for pest and disease control services, and subsoiling tillage services, from large professional households or cooperatives, so as to realize the purpose of capital investment as a replacement for labor input. Existing literature shows that agricultural socialized services have played an important role in promoting cleaner production, agricultural socialized service organizations use advanced clean technology and equipment to assist farmers in achieving cleaner production under the guidance of national policies [51,52]. In addition, the aging of the agricultural labor force leads to the gradual withdrawal of elderly farmers from agricultural production and the transfer of land management rights to cooperatives or enterprises. Large-scale operation is more conducive to the promotion of cleaner agricultural production technology [53]. Cleaner production needs new production factors such as advanced technology and scientific management to play a role, and gradually replace traditional factors. The deepening of factor substitution will undoubtedly help elderly farmers to participate in cleaner production.

Based on the above analysis, this article puts forward Hypothesis 2 (H2):

Hypothesis 2 (H2). Rural population aging has a positive impact on farmers' cleaner production behavior through factor substitution. 


\subsection{Social Network Effect}

As an informal channel for the dissemination of new technologies, social networks play an important role in the promotion of clean technologies. Generally speaking, the impact of a social network effect on production behavior will be enhanced with the increasing age of a population. The reason is that elderly farmers have deeper social communication, higher dependence on social networks, and find it easier to imitate others' cleaner production behaviors [54]. Firstly, the agricultural production mode has strong imitability. Within the village, people's environmental conditions and factor constraints are almost the same, their working habits are similar, and the homogeneity of technical interaction is high. Elderly farmers find it easy to imitate the behavior of others in the village [55]. Secondly, elderly farmers have an insufficient understanding of new knowledge and new technology. Their access to technical services mostly depends on the communication between relatives, friends and neighbors, and farmers are willing to imitate the agricultural production mode of rural elites.

Based on the above analysis, this article puts forward Hypothesis $3(\mathrm{H} 3)$ :

Hypothesis 3 (H3). Rural population aging has a positive impact on farmers' cleaner production behavior through behavior imitation.

In addition to the above three indirect mechanisms, rural population aging also has a direct impact on farmers' cleaner production behavior. According to the above hypotheses, this article constructs a theoretical analysis framework as in Figure 1.

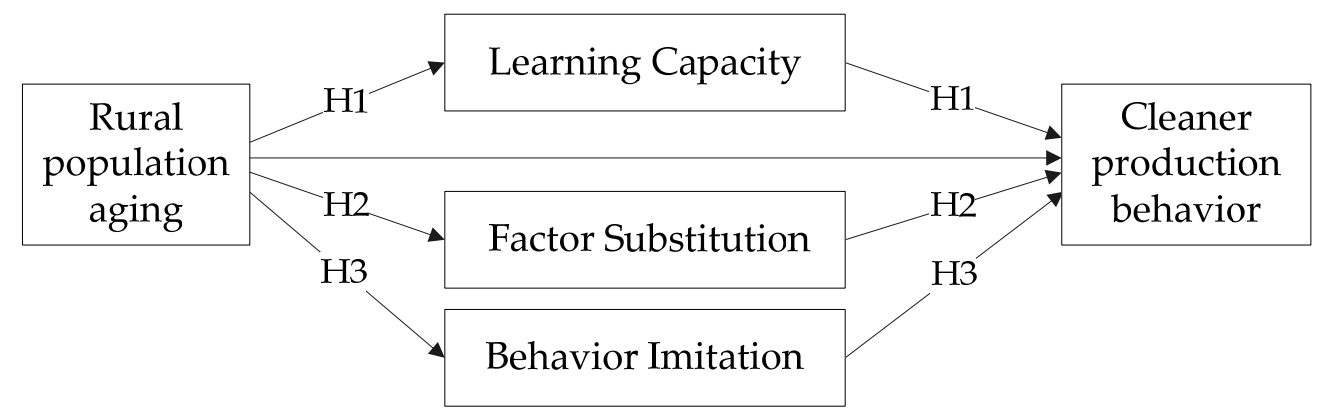

Figure 1. Theoretical analysis framework.

\section{Methodology and Data Sources}

\subsection{Data Sources}

The data used in this article were collected from a questionnaire survey of farmers in the main grain producing provinces of the North China Plain from July to September in 2019. The survey provinces include Hebei, Henan, Shandong, Anhui and Jiangsu. They are the key areas to promote cleaner agricultural production technology in China, and have good representativeness and reference value for the study of farmers' cleaner production behavior. The map shows the location of these provinces as in Figure 2. The North China Plain is an important grain production base in China, and also the plain with the largest population in China. The total area is 300,000 square kilometers, accounting for $3.1 \%$ of China's total land area, and the total population is 339 million, accounting for $24.2 \%$ of China's total population. The dominant crops in the North China Plain are wheat, rice and corn, which play an irreplaceable role in ensuring China's food security. 


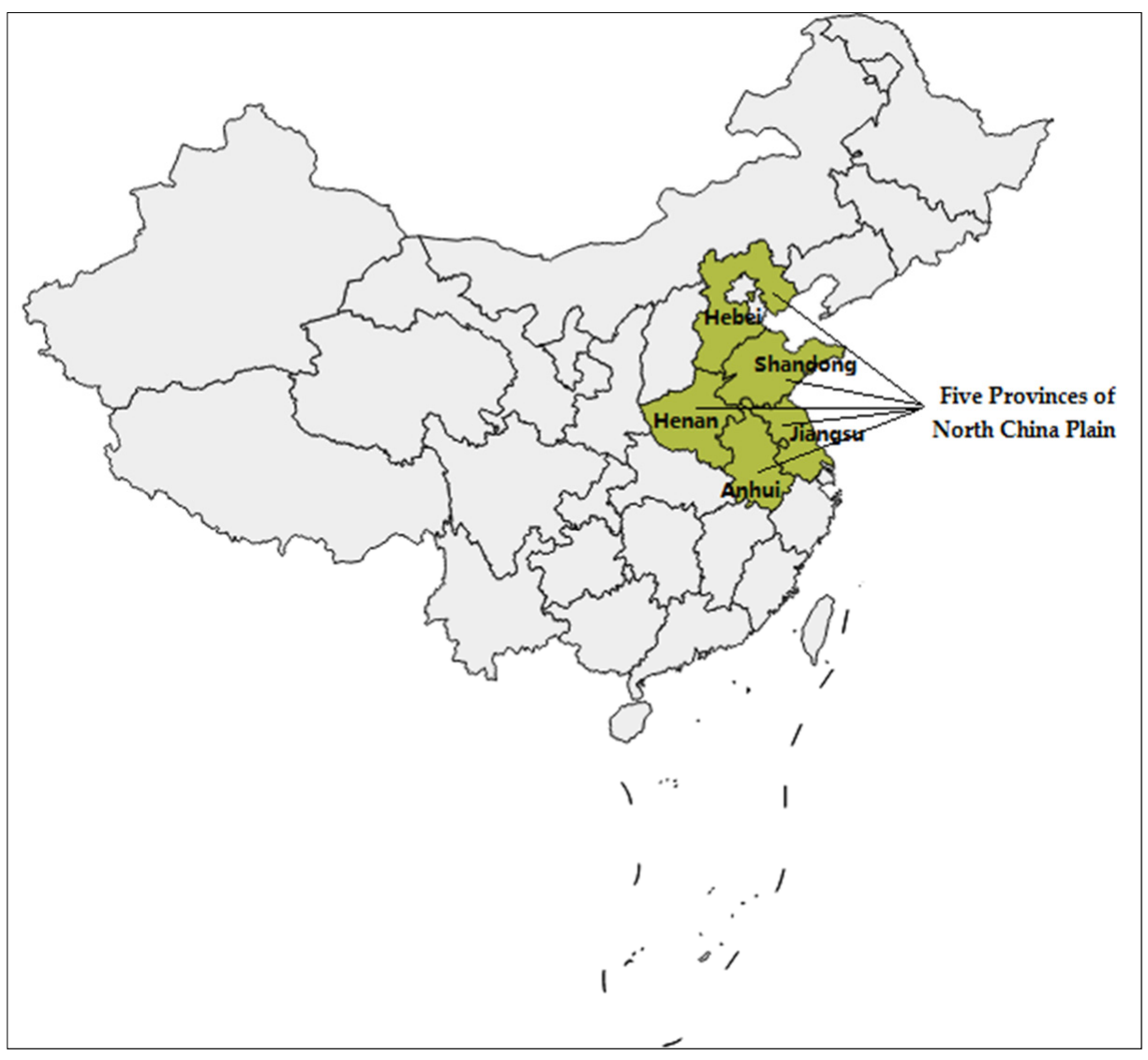

Figure 2. Location map of sample provinces in China.

This survey adopted the method of multi-stage stratified sampling and random sampling. Firstly, three counties were selected in each province, next, three sample towns were selected in each sample county, then, $2-3$ villages were randomly selected in each town, and finally, 10 farmers were selected in each village for investigation. In order to ensure the quality of the survey, all the investigators received professional training in the early stage. The questionnaires were communicated and filled in by investigators. The surveyed families are mainly engaged in planting grain. Each family sent a representative to participate in the survey. This representative is usually the head of household or the person in the family who is mainly involved in agricultural production decision-making. The basic family information of sample farmers is shown in Table 1. A total of 981 questionnaires were distributed in this survey. After eliminating invalid questionnaires, questionnaires with key information missing, logical errors and missing variables, a total of 916 valid questionnaires were collected. Items related to subjective answers were measured by a Likert five-dimension scale.

\subsection{Model}

Learning capacity, factor substitution and behavior imitation are difficult to measure directly and accurately. Therefore, they are latent variables and can only be measured indirectly by some observable indicators. Traditional statistical methods need to assume that the independent variables are error free and cannot deal with latent variables effectively. Structural equation models can analyze the complex relationship between multiple dependent variables and independent variables on the basis of dealing with latent variables which are difficult to observe [56]. Therefore, this article will use a structural equation model to analyze the mechanism and effect of rural population aging on farmers' cleaner production behavior. 
Table 1. Basic Family Information of Sample Farmers.

\begin{tabular}{cll}
\hline Variable & \multicolumn{1}{c}{ Categories } & Percentage (\%) \\
\hline \multirow{2}{*}{ Gender } & Male & 71.7 \\
& Female & 28.3 \\
& $\leq 50$ & 24.6 \\
& $51-60$ & 30.1 \\
& $61-70$ & 34.5 \\
Years of education & $\geq 71$ & 10.8 \\
& $\leq 6$ & 41.3 \\
& $7-9$ & 39.5 \\
Number of family labor force & $10-12$ & 17.1 \\
& $\geq 13$ & 2.1 \\
& $\leq 2$ & 43.3 \\
& $3-5$ & 50.1 \\
& $7-8$ & 6.4 \\
& $\geq 9$ & 0.2 \\
Cultivated land area (/ha) & $\leq 0.33$ & 29.7 \\
& $0.34-0.67$ & 35.5 \\
& $0.68-1.33$ & 19.3 \\
& $\geq 1.34$ & 15.5 \\
& $\leq 2$ & 15.9 \\
& $3-5$ & 39.2 \\
& $6-10$ & 30.3 \\
& $\geq 11$ & 14.6 \\
\hline
\end{tabular}

Structural equation models generally include structural equations and measurement equations. A structural equation is used to define the relationship between potential independent variables (rural population aging, learning capacity, factor substitution, behavior imitation) and potential dependent variables (learning capacity, factor substitution, behavior imitation, farmers' cleaner production behavior). Measurement equation is used to define the linear relationship between the above latent variables and the observed variables.

The structural equation is as follows:

$$
\eta=\mathrm{B} \eta+\Gamma \xi+\zeta
$$

where $\eta$ is an endogenous latent variable, which indicates farmers' cleaner production behavior, $\xi$ is an exogenous latent variable, which indicates the degree of farmers' aging, $B$ is the coefficient matrix of endogenous latent variable, $\Gamma$ is the coefficient matrix of exogenous latent variable and $\zeta$ is the residuals of the structural equation, which reflects the unexplained part of the equation.

The measurement equations are as follows:

$$
\begin{aligned}
& X=\Lambda_{X} \xi+\delta \\
& Y=\Lambda_{Y} \eta+\varepsilon
\end{aligned}
$$

where $X$ represents the exogenous observed variable, $Y$ represents the endogenous observed variable, $\Lambda_{\mathrm{X}}$ is the correlation coefficient matrix of exogenous latent variables and their observed variables, $\Lambda_{Y}$ is the correlation coefficient matrix of endogenous latent variables and their observed variables, and $\delta$ and $\varepsilon$ represent the residual terms of the two measurement equations respectively.

\subsection{Variable Description}

\subsubsection{Farmers' Cleaner Production Behavior}

Cleaner production is a sustainable production mode matching with the carrying capacity of resources and environment [5]. Six kinds of cleaner production technologies are selected in the survey, including seed coating, water saving irrigation, soil testing and for- 
mulated fertilization, subsoiling tillage, green technology for pest and disease control, and straw returning. These technologies can cover the main links of agricultural production [8]. In the survey, investigators will provide the above six cleaner production technologies for respondents to choose from. There are two ways for farmers to use clean technology: one is done by the farmer, and the other is used through the purchase of agricultural socialized services. Either way, it represents that the farmer has used agricultural clean technology on the land. We use the following items to measure farmers' cleaner production behavior [57-59]: “Do you use cleaner production technology?" (CPB1); "How many clean production technologies are used in your family?" (CPB2); "What is the percentage of cultivated land in your family that adopts cleaner production technology?" (CPB3); "Do you actively participate in the training of cleaner production technology?" (CPB4).

\subsubsection{Rural Population Aging}

Rural population aging should consider not only the number of rural elderly people, but also the age structure of the rural elderly population. Therefore, we use the following three items to measure rural population aging [40,60]: "What is the average age of the labor force engaged in agricultural production in your family?" (AGE1); "What's the percentage of the population aged 60 or above in your family?" (AGE2); "What's the age of the agricultural production decision maker in your family?" (AGE3).

\subsubsection{Learning Capacity}

Learning capacity refers to farmers' ability to acquire, identify, understand, and apply cleaner production technologies. If farmers have a strong learning capacity, it will help to promote farmers' continuous learning, and help them to fully understand and apply the obtained cleaner production technology, so as to improve production efficiency. We measure the learning capacity of the interviewees through the following four items [61-63]: "Do you often discover new technologies earlier than others around you?" (LC1); "Do you often quickly know the characteristics and functions of the new technology?" (LC2); "Do you have enough ability to understand the new technology?" (LC3); "Do you often learn to use new technology quickly?" (LC4).

\subsubsection{Factor Substitution}

The level of factor substitution measures the extent to which farmers' labor input is replaced by mechanization, capital, outsourcing service, and modern field management [64]. The existing research mainly uses a single index to analyze the substitution of machinery for labor and chemical fertilizer application for labor [65]. There are many links in agricultural production, so it is difficult to quantify with a single index. This paper measures the degree of factor substitution of farmers by the following four items [8,57-59]: "Is your crop pest control mainly done by others?" (FS1); "Is your planting and transplanting mainly done by others?" (FS2); "Is your plowing and harvesting mainly done by others?" (FS3); "Would you rather buy outsourcing services than learn new technologies?" (FS4).

\subsubsection{Behavior Imitation}

Behavior imitation is a type of learning method of adopting new skills or improving skills by observing and imitating the behavior of other individuals or organizations [66]. The existing literature mainly discusses the influence of other individuals or organizations in the production decision-making process from the perspective of collective decisionmaking, peer effect, social network, and subjective norms [67-72]. This paper measures the degree of behavior imitation through the following four items: "Do you mainly follow others in agricultural production technology?" (BI1); "Do you mainly follow others in your choice of planting varieties?" (BI2); "Do you mainly follow others for your choice of planting structure?" (BI3); "Do you mainly follow others in choosing the brand of chemical fertilizer and pesticide?" (BI4). 


\subsubsection{Control Variables}

We also selected five control variables: level of education, the number of family labor force, fragmentation degree of cultivated land, field road condition and the intensity of government's promotion of cleaner agricultural production [48].

\section{Results and Discussion}

\subsection{Reliability and Validity Test}

Cronbach's $\alpha$ coefficient and composite reliability (CR) are used to test the stability and internal consistency of latent variables. All values of Cronbach's $\alpha(0.801,0.824,0.859$, 0.889 and 0.901$)$ and composite reliability values $(0.822,0.838,0.852,0.873$ and 0.881$)$ are greater than 0.7 (See Table 2), which indicates the questionnaire has high reliability. The average variance extraction (AVE) $(0.607,0.564,0.592,0.635$ and 0.651$)$ of all potential variables are greater than 0.5 , which shows that potential variables can explain more than half of the measured variables. Estimated standardized path coefficients are greater than 0.6 , so the measurement scale has good convergent validity.

Table 2. Reliability and Validity of the Scales.

\begin{tabular}{|c|c|c|c|c|c|}
\hline Scale & Items & Cronbach's $\alpha$ & $\begin{array}{l}\text { Factor } \\
\text { Loadings }\end{array}$ & CR & AVE \\
\hline \multirow{4}{*}{ Rural population aging (AGE) } & AGE1 & \multirow{3}{*}{0.801} & 0.709 & \multirow{4}{*}{0.822} & \multirow{4}{*}{0.607} \\
\hline & AGE2 & & 0.801 & & \\
\hline & AGE3 & & 0.823 & & \\
\hline & LC1 & \multirow{4}{*}{0.824} & 0.787 & & \\
\hline \multirow{3}{*}{ Learning capacity (LC) } & LC2 & & 0.692 & \multirow{3}{*}{0.838} & \multirow{3}{*}{0.564} \\
\hline & LC3 & & 0.752 & & \\
\hline & LC4 & & 0.769 & & \\
\hline \multirow{4}{*}{ Factor substitution (FS) } & FS1 & \multirow{4}{*}{0.859} & 0.829 & \multirow{5}{*}{0.852} & \multirow{5}{*}{0.592} \\
\hline & FS2 & & 0.634 & & \\
\hline & FS3 & & 0.814 & & \\
\hline & FS4 & & 0.784 & & \\
\hline \multirow{3}{*}{ Behavior imitation (BI) } & BI1 & \multirow{4}{*}{0.889} & 0.692 & & \\
\hline & $\mathrm{BI} 2$ & & 0.709 & \multirow{3}{*}{0.873} & \multirow{3}{*}{0.635} \\
\hline & $\mathrm{BI} 3$ & & 0.858 & & \\
\hline \multirow{5}{*}{$\begin{array}{l}\text { Cleaner production behavior } \\
\qquad(\mathrm{CPB})\end{array}$} & BI4 & & 0.907 & & \\
\hline & CPB1 & \multirow{4}{*}{0.901} & 0.709 & \multirow{4}{*}{0.881} & \multirow{4}{*}{0.651} \\
\hline & CPB2 & & 0.719 & & \\
\hline & CPB3 & & 0.918 & & \\
\hline & CPB4 & & 0.861 & & \\
\hline
\end{tabular}

In order to test the discriminant validity between latent variables, Pearson correlation coefficients are calculated. The square root of AVE is placed in the diagonal position of a correlation coefficient matrix for comparative analysis (See Table 3). The square root of every AVE is larger than any correlation coefficient of all other latent variables, which indicates the measurement scale has good discriminant validity.

Table 3. Pearson correlation and discriminant validity test results.

\begin{tabular}{cccccc}
\hline Latent Variable & AGE & AC & FS & BI & CPB \\
\hline AGE & 0.779 & & & & \\
LC & -0.089 & 0.751 & & & \\
FS & 0.116 & -0.401 & 0.769 & & \\
BI & 0.078 & -0.498 & 0.398 & 0.797 & \\
CPB & -0.167 & -0.045 & 0.029 & 0.134 & 0.807 \\
\hline
\end{tabular}

Note: Square root of AVE is on the diagonal. 


\subsection{Model Overall Fitness Test}

The results of the model overall fitness test are $\chi^{2} / \mathrm{df}=2.989$, RMSEA $=0.052$, $\mathrm{GFI}=0.908, \mathrm{AGFI}=0.912, \mathrm{TLI}=0.903, \mathrm{CFI}=0.908$. All the index values are in the recommended range, which shows that the overall fitness of the model is good.

\subsection{Direct Effect Analysis}

The direct effect of rural population aging on farmers' cleaner production behavior is significantly negative $(p<0.01)$, and the path coefficient is -0.112 (see Table 4$)$. This shows the decision-making of farmers in China is conservative with aging, which affects farmers' acceptance of the concept of cleaner agricultural production. Therefore, as the direct decision-maker and implementer of agricultural production, rural population aging has a negative impact on cleaner agricultural production.

Table 4. SEM estimation of the impact of aging labor force on green grain production behavior of farmers.

\begin{tabular}{lcccc}
\hline Path & $\begin{array}{c}\text { Unstandardized } \\
\text { Estimate }\end{array}$ & S.E. & Z-Value & $\begin{array}{c}\text { Standardized } \\
\text { Estimate }\end{array}$ \\
\hline $\mathrm{AGE} \rightarrow \mathrm{LC}$ & $-0.511^{* * *}$ & 0.151 & -3.384 & -0.086 \\
$\mathrm{AGE} \rightarrow \mathrm{FS}$ & $0.598^{* * *}$ & 0.164 & 3.646 & 0.098 \\
$\mathrm{AGE} \rightarrow \mathrm{BI}$ & $0.401^{* *}$ & 0.161 & 2.491 & 0.079 \\
$\mathrm{AGE} \rightarrow \mathrm{CPB}$ & $-0.398^{* * *}$ & 0.101 & -3.941 & -0.112 \\
$\mathrm{LC} \rightarrow \mathrm{CPB}$ & $0.383^{* * *}$ & 0.062 & 6.177 & 0.193 \\
$\mathrm{FS} \rightarrow \mathrm{CPB}$ & $0.421^{* * *}$ & 0.065 & 6.477 & 0.231 \\
$\mathrm{BI} \rightarrow \mathrm{CPB}$ & $0.289^{* * *}$ & 0.057 & 5.070 & 0.154 \\
$\mathrm{EDU} \rightarrow \mathrm{CPB}$ & $0.021^{* *}$ & 0.009 & 2.333 & 0.078 \\
Labor number $\rightarrow \mathrm{CPB}$ & $0.188^{* * *}$ & 0.029 & 6.483 & 0.181 \\
Farmland fragmentation $\rightarrow \mathrm{CPB}$ & $-0.081^{* * *}$ & 0.019 & -4.263 & -0.112 \\
Road condition $\rightarrow \mathrm{CPB}$ & $0.132^{* * *}$ & 0.037 & 3.568 & 0.109 \\
Government $\rightarrow \mathrm{CPB}$ & $0.051^{* * *}$ & 0.010 & 5.100 & 0.139 \\
\hline
\end{tabular}

Note: ${ }^{* * *} p<0.01,{ }^{* *} p<0.05$.

Rural population aging has a significant negative impact on learning capacity $(p<0.05)$, and the path coefficient is -0.086 (see Table 4 ). With the deepening of the aging degree, the physical strength of the agricultural labor force gradually decreases, and their learning motivation and ability to learn new knowledge and new technology will gradually decrease because of the decline of their human capital [38]. Accordingly, their ability to acquire, digest and apply new knowledge and new technology will further weaken.

Rural population aging has a significant positive impact on factor substitution $(p<0.01)$, and the path coefficient is 0.098 (see Table 4). The aging has changed the endowment of production factors of farmers. Farmers need to readjust the allocation of factors, give up the control of all or part of the production links, especially reduce the labor input in each link of production, and replace it with agricultural machinery services or other outsourcing services. This provides a chance for the entry of modern factors. Therefore, agricultural population aging contributes to the deepening of factor substitution to a certain extent.

Rural population aging has a significant positive impact on behavior imitation $(p<0.05)$, and the path coefficient is 0.079 (see Table 4). The higher the degree of aging, the more dependent farmers' production behaviors are on the outside world [54]. For example, compared with the young labor force, the rural social network of the elderly labor force is closer and more vulnerable to the influence of other individuals or organizations in the network. They also lack the initiative to make production decisions and tend to follow the behaviors of surrounding people. Therefore, the aging of rural population makes it easier for farmers to listen to the suggestions of others or organizations in cleaner production decision-making.

Learning capacity has a significant positive impact on farmers' cleaner production behavior $(p<0.01)$, and the path coefficient is 0.193 (see Table 4 ). Learning capacity 
reflects farmers' ability to acquire, understand and apply cleaner production technology. Therefore, the higher the learning capacity, the less difficult it is for farmers to understand and internalize cleaner production technology, which is helpful for farmers to participate in cleaner production $[61,63]$.

Factor substitution has a significant positive impact on farmers' cleaner production behavior $(p<0.01)$, and the path coefficient is 0.231 (see Table 4$)$. The level of factor substitution measures the extent to which farmers' labor input is replaced by capital, outsourcing services, and modern management in the process of agricultural production [64]. The deepening of the degree of factor substitution is helpful to improve the degree of social division of cleaner agricultural production, which provides the possibility of further development for cleaner agricultural production [65].

Behavior imitation also has a significant positive impact on farmers' cleaner production behavior $(p<0.01)$, and the path coefficient is 0.154 (see Table 4$)$. The higher the degree of farmers' behavior imitation, the more likely they are to adopt the views and suggestions of rural authorities or organizations, the stronger the binding force of social norms on them, and the more likely they are to participate in cleaner production $[69,70]$.

Education level has a significant positive impact on farmers' cleaner production behavior $(p<0.05)$, and the path coefficient is 0.078 (see Table 4 ). These results suggest that farmers with higher education tend to accept new things. They have a stronger ability to absorb cleaner production technology and imitate cleaner production behavior, so they are more likely to adopt cleaner agricultural production modes [48]. Labor number has a significant positive impact on farmers' cleaner production behavior $(p<0.01)$, and the path coefficient is 0.181 (see Table 4). Although some cleaner agricultural production links have been replaced by mechanical operation, the number of agricultural labor force is still an important guarantee for field farming management to a certain extent, which has an important impact on the production mode of farmers. Farmland fragmentation has a significant negative impact on farmers' cleaner production behavior $(p<0.01)$, and the path coefficient is -0.112 (see Table 4). Farmland fragmentation has been an important factor restricting farmers to adopt cleaner production technology for a long time [52]. It not only causes higher costs of transportation, time, and manpower, but also makes it difficult to effectively play the scale effect of technology adoption, which is not conducive to farmers' cleaner production. The field road condition has a significant positive impact on farmers' cleaner production behavior ( $p<0.01$ ), and the path coefficient is 0.109 (see Table 4). Good field road conditions can significantly improve the possibility of popularization of mechanical cleaner production technology (such as subsoiling tillage) and create a good external environment for farmers' cleaner production. Government promotion has a significant positive impact on farmers' cleaner production behavior $(p<0.01)$, and the path coefficient is 0.139 (see Table 4). The government adopts a variety of publicity methods to form a social atmosphere for the extensive development of cleaner production and makes full use of television, newspapers, internet and other publicity media to carry out special reports on cleaner agricultural production, hold various knowledge lectures and introduce cleaner production demonstration results, which help farmers adopt cleaner production technologies [71].

\subsection{Mediating Effect Test}

Indirect effect means one variable influences another through at least one intermediary variable. There may also be significant indirect effects between rural population aging and clean production behavior. Bootstrapping takes the research sample as the sampling population, uses repeated sampling technology to repeatedly extract a certain number of samples from the research sample, and takes the average parameters obtained from each sampling as the final estimation result. If the $95 \%$ confidence interval of the regression coefficient product does not contain 0 , the mediating effect is valid [72]. This method can overcome the error of confidence interval estimation caused by the non-normal distribution of a mediating effect to a large extent, and it is an ideal method to test mediating effects at 
present [73]. In addition, the bootstrapping method can also judge the significance of each intermediate transmission mechanism, which is an advantage that traditional test methods do not have.

The indirect effect of learning capacity (LC) is -0.196 (see Table 5), and bias-corrected bootstrapped $95 \%$ confidence interval $[-0.367,-0.058]$ and percentile $95 \%$ confidence interval $[-0.332,-0.017]$ do not contain 0 . This result suggests that rural population aging has a significant negative effect on farmers' cleaner production behavior through learning capacity, which verifies Hypothesis 1 . In other words, the weakening learning capacity is one of the important factors hindering the adoption of cleaner production.

Table 5. Bootstrap Test Results for the Mediating Effect.

\begin{tabular}{lccccc}
\hline \multirow{2}{*}{$\begin{array}{c}\text { Transmission } \\
\text { Mechanism }\end{array}$} & \multirow{2}{*}{$\begin{array}{c}\text { Product of } \\
\text { Coefficients }\end{array}$} & \multicolumn{2}{c}{ Bias-Corrected (95\% CI) } & \multicolumn{2}{c}{ Percentile (95\% CI) } \\
\cline { 3 - 6 } & & Lower & Upper & Lower & Upper \\
\hline AGE $\rightarrow$ LC $\rightarrow$ CPB & -0.196 & -0.367 & -0.058 & -0.332 & -0.017 \\
AGE $\rightarrow$ FS $\rightarrow$ CPB & 0.252 & 0.078 & 0.491 & 0.065 & 0.487 \\
AGE $\rightarrow$ BI $\rightarrow$ CPB & 0.116 & 0.031 & 1.432 & 0.025 & 1.501 \\
Total indirect effect & 0.172 & 0.087 & 0.276 & 0.075 & 0.289 \\
Direct effect & -0.398 & -0.518 & -0.178 & -0.502 & -0.111 \\
Total effect & -0.226 & -0.321 & -0.101 & -0.329 & -0.099 \\
LC vs. FS & 0.447 & 0.141 & 0.953 & 0.067 & 0.801 \\
FS vs. BI & -0.136 & -0.241 & -0.032 & -0.265 & -0.054 \\
LC vs. BI & 0.312 & 0.081 & 0.513 & 0.091 & 0.591 \\
\hline
\end{tabular}

Note: The product of coefficients is the product of nonstandard estimation coefficients.

The indirect effects of factor substitution (FS) and behavior imitation (BI) are 0.252 and 0.116 respectively, which have passed the mediating effect test. The results show that rural population aging has a significant positive impact on farmers' cleaner production behavior through factor substitution and behavior imitation, which verifies Hypothesis 2 and Hypothesis 3 respectively. This means that the deepening of factor substitution and the improvement of external dependence of production decision-making brought by the aging of the population promote the participation level of farmers in cleaner production and bring important opportunities for the development of cleaner agricultural production.

The total indirect effect is 0.172 and passes the significance test. The direct effect is -0.398 and passes the significance test (see Table 5). We find that although the total indirect effect is positive, the direct effect is negative and the influence is greater than the total indirect effect. Therefore, in general, rural population aging has a significant negative impact on farmers' cleaner production behavior, and the total effect is -0.226 . The results show that there are significant differences among the three intermediate transmission mechanisms. The positive effect of factor substitution is significantly higher than that of the other two, which means we should pay more attention to the opportunities brought by factor substitution and create a good platform and environment for further improving the degree of factor substitution.

\section{Conclusions and Policy Implications}

Based on survey data of 916 farmers in five major grain producing provinces of the North China Plain in 2019, this paper used structural equation model and bootstrapping methods to empirically test the mechanism and effect of rural population aging on farmers' cleaner production behavior. The results are as follows: first, aging of the rural population reduces farmers' learning capacity, but has a positive effect on factor substitution and behavior imitation. Furthermore, we find learning capacity, factor substitution and behavior imitation have positive effects on farmers' cleaner production behavior. Second, the results of mediating effect test show rural population aging does affect farmers' cleaner production behavior through three intermediate transmission mechanisms: learning capacity, factor substitution and behavior imitation, but there are significant differences in these effects. Population aging has played a positive role in promoting farmers' participation in cleaner 
production through the mechanism of factor substitution and behavior imitation, which is more than the negative role through the mechanism of learning capacity, thus making the total indirect effect positive. Third, although the total indirect effect of population aging on farmers' cleaner production behavior is positive, the total effect is negative. This is because the direct effect of rural population aging on cleaner production is negative, and greater than the positive effect of indirect effect. Last, education level, the number of agricultural labor force, field road conditions and government promotion intensity have positive effects on farmers' cleaner production behavior, while farmland fragmentation has negative effects on it.

Based on the above conclusions, we find that the aging of the rural population has an adverse effect on cleaner production. Therefore, first of all, improve the degree of agricultural mechanization, research easy-to-learn and easy-to-use cleaner agricultural production technology to reduce the dependence of cleaner production on labor. Secondly, strengthen the construction and investment of agricultural socialized service system. Thirdly, we should give full play to the important role of social network in cleaner agricultural production and build a public social mutual aid platform for rural elderly groups.

Author Contributions: Conceptualization, S.D., J.L. and Z.F.; data curation, S.D., J.L.; data analysis, S.D., J.L.; writing-original draft, S.D., J.L. and Z.F.; writing-review and editing, J.L. and Z.F. All authors have read and agreed to the published version of the manuscript.

Funding: This research was funded by the National Natural Science Foundation of China (71903080).

Institutional Review Board Statement: Ethical review and approval were waived for this study, due to the fact that we used anonymous data that was not traceable to individuals at any time.

Informed Consent Statement: Not applicable.

Data Availability Statement: The data presented in this study are available on request from the corresponding author.

Conflicts of Interest: The authors declare no conflict of interest.

\section{References}

1. Wang, J.; Wei, X.; Guo, Q. A three-dimensional evaluation model for regional carrying capacity of ecological environment to social economic development: Model development and a case study in China. Ecol. Indic. 2018, 89, 348-355. [CrossRef]

2. Guo, H.P.; Xu, B.C.; Li, C.X.; Shu, K.L. Pesticide and fertilizer regulation: American experiences and enlightenment. Environ. Prot. 2015, 43, 64-69. [CrossRef]

3. Wang, H.; Wang, L.; Yang, G.; Jia, L.; Yao, Y.; Zhang, Y. Agricultural water resource in China and strategic measures for its efficient utilization. Strategy Stud. CAE 2018, 20, 9-15. [CrossRef]

4. Du, S.; Liu, J.; Fu, Z. The Impact of Village Rules and Formal Environmental Regulations on Farmers' Cleaner Production Behavior: New Evidence from China. Int. J. Environ. Res. Public Health 2021, 18, 7311. [CrossRef] [PubMed]

5. Yokamo, S. Adoption of Improved Agricultural Technologies in Developing Countries: Literature Review. Int. J. Food Sci. Agric. 2020, 4, 25-36. [CrossRef]

6. Madanhire, I.; Mugwindiri, K.; Mbohwa, C. Enhancing cleaner production application in fertilizer manufacturing: Case study. Clean Technol. Environ. Policy 2015, 17, 667-679. [CrossRef]

7. Miller, G.; Burke, J.; Mccomas, C.; Dick, K. Advancing pollution prevention and cleaner production-USA's contribution. J. Clean. Prod. 2008, 16, 665-672. [CrossRef]

8. Le, T.H.; Schnitzer, H.; Thanh, T.V.; Thao, N.T.P.; Braunegg, G. An integrated eco-model of agriculture and small-scale industry in craft villages toward cleaner production and sustainable development in rural areas-A case study from mekong delta of viet nam. J. Clean. Prod. 2016, 137, 274-282. [CrossRef]

9. Lopreite, M.; Zhu, Z. The effects of ageing population on health expenditure and economic growth in China: A Bayesian-VAR approach. Soc. Sci. Med. 2020, 265, 113513. [CrossRef] [PubMed]

10. Liao, L.; Long, H.; Gao, X.; Ma, E. Effects of land use transitions and rural aging on agricultural production in china's farming area: A perspective from changing labor employing quantity in the planting industry. Land Use Policy 2019, 88, 104152. [CrossRef]

11. World Health Organization (WHO). World Health Statistics 2016: Monitoring Health for the SDGs, Sustainable Development Goals; World Health Organization: Geneva, Switzerland, 2016.

12. United Nations (LTN). World Population Prospects: The 2017 Revision; United Nations Publications: New York, NY, USA, 2017.

13. Wan, H.; Goodkind, D.; Kowal, P. An Aging World: 2015; U.S. Government Publishing Office: Washington, DC, USA, 2016. 
14. Lutz, W.; Sanderson, W.; Scherbov, S. The coming acceleration of global population ageing. Nature 2008, 451, 716-719. [CrossRef] [PubMed]

15. United Nations Population Fund (LTNFPA). Ageing in the Twenty-First Century: A Celebration and a Challenge; United Nations Population Fund (UNFPA): New York, NY, USA; Help Age International: London, UK, 2012.

16. Lin, L.; Ma, F. Spatial distribution and trends of the aging of population in Guangzhou. Geogr. Res. 2007, 26, 1043-1054. [CrossRef]

17. Weeks, J. Population: An Introduction to Concepts and Issues; Nelson Education: New York, NY, USA, 2011.

18. Herrmann, M. Population aging and economic development: Anxieties and policy responses. J. Popul. Ageing 2012, 5, 23-46. [CrossRef]

19. Banister, J.; Bloom, D.E.; Rosenberg, L. Population aging and economic growth in China. In The Chinese Economy; Palgrave Macmillan: London, UK, 2012. [CrossRef]

20. Zabalza, A.; Piachaud, D. Social security and the elderly: A simulation of policy changes. J. Public Econ. 1981, 16, 145-169. [CrossRef]

21. Greve, W.; Staudinger, U.M. Resilience in Late Adulthood and Old Age: Resources and Potentials for Successful Aging; John Wiley \& Sons, Inc.: Hoboken, NJ, USA, 2006.

22. Strunk, B.C.; Ginsburg, P.B.; Banker, M.I. The effect of population aging on future hospital demand. Health Aff. 2006, 25, 141-149. [CrossRef]

23. Glasgow, N.; Brown, D.L. Rural ageing in the United States: Trends and contexts. J. Rural Stud. 2012, 28, 422-431. [CrossRef]

24. Zhang, N.J.; Guo, M.; Zheng, X. China: Awakening giant developing solutions to population aging. Gerontologist 2012, 52, 589-596. [CrossRef] [PubMed]

25. Liu, Y.S. Research on the urban-rural integration and rural vitalization in the new era in China. Acta Geogr. Sin. 2018, 73, 637-650. [CrossRef]

26. Li, C.; Luo, R.D. Aging, grandparcnting and rural out-migration: A study based on the micro perspective of family decisions. Comp. Econ. Soc. Syst. 2017, 2, 135-146.

27. Chen, C.H.; Liu, T.K.; Dai, J.J. TFP growth, decomposition and the determinants of the decomposed effects-An empirical study on Japanese regional farming families. Int. J. Econ. Perspect. 2010, 4, 537-552.

28. Xiang, Y.; Qi, C.J.; Hu, X.Y. The influence of aging, concurrent industry and feminization on the household production factors input: An empirical analysis based on national rural fixed observation point data. Stat. Inf. Forum 2018, 33, 109-115. [CrossRef]

29. Qiu, J.J.; Ren, Q.; Yu, J. Aging of agricultural labor, agricultural capital investment and land use efficiency: Based on a longitudinal survey of farmers in Shandong, Henan and Anhui. Res. Sci. 2019, 41, 1982-1996. [CrossRef]

30. Liu, J.J.; Sun, H. Does aging impact China's agricultural production?-Observations based on wheat, rice and corn. Northwest Popul. 2017, 38, 71-76. [CrossRef]

31. Wei, J.Y.; Xia, W. The impact of rural population aging on the change of grain yield in China-Empirical analysis based on panel data of the main grain-producing areas. J. Agrotech. Econ. 2018, 12, 41-52. [CrossRef]

32. Zhou, J. The possibility and significance of agriculture under the background of aging: The experience and revelation of south Korea. Popul. Dev. 2017, 23, 36-45.

33. Peng, D.Y.; Wen, L. Is the aging and feminization of rural labor reducing the efficiency of grain production: A comparative analysis of north and south based on stochastic frontier. J. Agrotech. Econ. 2016, 2, 32-44.

34. Wang, S.G.; Tian, X. The Influence of Rural Labor Force Aging on Agricultural Production-An empirical analysis of cultivated land terrain. J. Agrotech. Econ. 2018, 4, 15-26.

35. Zhang, R.J. Regional differences and comparison of land circulation affecting rural population aging. J. Agrotech. Econ. 2017, 9, 14-23.

36. Schultz, T.W. Transforming Traditional Agriculture; Yale University Press: New Haven, CT, USA; London, UK, 1964.

37. Mothe, C.; N'Guyen, T.T. Does age diversity boost technological innovation? Exploring the moderating role of HR practices. Eur. Manag. J. 2021, 3. in press. [CrossRef]

38. Verhaegen, P.; Salthouse, T.A. Meta-analyses of Age-cognition Relations in Adulthood: Estimates of Linear and Nonlinear Age Effects and Structural Models. Psychol. Bull. 1997, 122, 231-249. [CrossRef]

39. Zhang, X.; Yang, J.; Thomas, R. Mechanization outsourcing clusters and division of labor in Chinese agriculture. China Econ. Rev. 2017, 43, 184-195. [CrossRef]

40. He, L.X.; Nan, Y.Q.; Zhang, Z.G. Aging, social network and household's farming: Evidence from CFPS. Econ. Rev. 2016, 2, 85-97.

41. Deng, X.; Zhang, W. Will Population Aging Hinder Technological Progress-Empirical Evidence from China in 2000-2014. J. Huazhong Univ. Sci. Technol. 2018, 32, 28-38. [CrossRef]

42. Inwood, S. Agriculture, health insurance, human capital and economic development at the rural-urban-interface. J. Rural Stud. 2017, 54, 1-14. [CrossRef]

43. Jones, B.F. Age and great invention. Rev. Econ. Stat. 2010, 92, 1-14. [CrossRef]

44. Kanfer, R.; Ackerman, P. Individual differences in work motivation: Further explorations of a trait framework. Appl. Psychol. 2000, 49, 470-482. [CrossRef]

45. Almarshudi, A.S.; Kotagama, H. Socio-Economic structure and performance of traditional Fishermen in the Sultanate of Oman. Maine Res. Econ. 2006, 21, 221-230. [CrossRef] 
46. Cohen, W.M.; Levinthal, D.A. Absorptive capacity: A new perspective on learning and innovation. Admin. Sci. Q. 1990, 35, 128-152. [CrossRef]

47. Santos, J.; Roldan, L.B.; Loo, M. Clarifying relationships between networking, absorptive capacity and financial performance among south brazilian farmers. J. Rural Stud. 2021, 84, 90-99. [CrossRef]

48. Wang, J.X.; Wang, S.J. Population aging, technological innovation and economic growth-From the Perspective of structural change of factor endowments. J. Xi'an Jiaotong Univ. 2017, 37, 27-38. [CrossRef]

49. Acemoglu, D. Equilibrium bias of technology. Econometrica 2007, 75, 1371-1409. [CrossRef]

50. Li, J.; Li, Y. Influence measurement of rapid urbanization on agricultural production factors based on provincial panel data. Socio-Econ. Plan. Sci. 2019, 67, 69-77. [CrossRef]

51. Shen, X.X.; Duan, J.Y.; Zhu, S.Y. Exploring research on socialized services patterns for green agricultural production. Chin. J. Agric. Res. Reg. Plan. 2020, 41, 15-20. [CrossRef]

52. Department of Science, Technology and Education of Ministry of Agriculture and Rural Affairs of the People's Republic of China. Report on the Development of Agricultural and Rural Science and Technology in China (2012-2017); China Agriculture Press: Beijing, China, 2018.

53. Han, J.B.; Liu, S.Y.; Zhang, S.F.; Liu, Y.F. Influence of aging of agricultural labor force on large-scale management of land. Res. Sci. 2019, 41, 2284-2295. [CrossRef]

54. Zhao, Q.Q.; Shen, J.L.; Xia, X.L. Effects of aging agricultural labor force and social network embedding on farmers' access to agricultural technology extension services. J. Huazhong Agric. Univ. 2020, 4, 79-88. [CrossRef]

55. Wang, L.; Yang, X.H.; Jiang, M.D. Research on farmers' willingness to participate in the supply of small irrigation and water conservancy facilities from the perspective of social network relationship embeddedness. Rural Econ. 2019, 4, 111-117.

56. Sarkar, A.; Azim, J.A.; Asif, A.A.; Qian, L.; Peau, A.K. Structural equation modeling for indicators of sustainable agriculture: Prospective of a developing country's agriculture. Land Use Policy 2021, 109, 105638. [CrossRef]

57. Chanda, M.; Groote, H.D.; Kinoti, L. Farmer evaluation of pesticide seed-coating to control fall armyworm in maize. Crop Prot. 2021, 148, 105691. [CrossRef]

58. Soul-kifouly, G.; Midingoyi, K.M.; Muriithi, B.; Diiro, G.; Ekesi, S. Do farmers and the environment benefit from adopting integrated pest management practices? Evidence from Kenya. J. Agric. Econ. 2019, 70, 452-470. [CrossRef]

59. Ezzat, S.M.; Jeevanandam, J.; Bsc, C.E. Semiochemicals: A Green Approach to Pest and Disease Control. In Natural Remedies for Pest, Disease and Weed Control; Academic Press: Cambridge, MA, USA, 2020; pp. 81-89. [CrossRef]

60. Skevas, I.; Emvalomatis, G.; Brümmer, B. The effect of farm characteristics on the persistence of technical inefficiency: A case study in German dairy farming. Eur. Rev. Agric. Econ. 2018, 45, 1-23. [CrossRef]

61. Wei, Y. Corporate social capital and technological innovation: An empirical research based on perspective of absorptive capacity. China Ind. Econ. 2007, 9, 119-127. [CrossRef]

62. Duan, Y.; Wang, W.; Zhou, W. The multiple mediation effect of absorptive capacity on the organizational slack and innovation performance of high-tech manufacturing firms: Evidence from Chinese firms. Int. J. Prod. Econ. 2020, 229, 107754. [CrossRef]

63. Martínez-Sánchez, A.; Vicente-Oliva, S.; Pérez-Pérez, M. The relationship between R\&D, the absorptive capacity of knowledge, human resource flexibility and innovation: Mediator effects on industrial firms. J. Bus. Res. 2020, 118, 431-440. [CrossRef]

64. Li, T.; Sun, X.L.; Feng, K.W. The design of food security system based on feasible ability theory in China: Labor transfer, logic of factor substitution and feasible ability improvement. Econ. Prob. 2021, 7, 100-108. [CrossRef]

65. Hu, H.; Yang, Y.B. Study on fertilizer application of farmers under the perspective of factor substitution: Famers' data based on national coral fixed observation points. J. Agrotech. Econ. 2015, 3, 84-91.

66. Okawa, T.; Takeno, J. Development of self-cognition through imitation behavior. Procedia Comp. Sci. 2016, 88, 46-51. [CrossRef]

67. Hang, X.; Dpa, B.; Sk, C. Peer effects in the diffusion of innovations: Theory and simulation. J. Behav. Exp. Econ. 2016, 63, 1-13. [CrossRef]

68. Maertens, A.; Barrett, C.B. Measuring social networks' effects on agricultural technology adoption. Am. J. Agric. Econ. 2013, 95, 353-359. [CrossRef]

69. Ramachandran, A.; Enserink, B.; Balchand, A.N. Coastal regulation zone rules in coastal panchayats (villages) of Kerala, India vis-à-vis socio-economic impacts from the recently introduced peoples' participatory program for local self-governance and sustainable development. Ocean Coast. Manag. 2005, 48, 632-653. [CrossRef]

70. Helmke, G.; Levitsky, S. Informal institutions and comparative politics: A research agenda. Perspect. Politics 2004, 2, 725-740. [CrossRef]

71. Li, H.; He, F.; Deng, G. How does environmental regulation promote technological innovation and green development? New evidence from China. Pol. J. Environ. Stud. 2019, 29, 689-702. [CrossRef]

72. Baron, R.M.; Kenny, D.A. The moderator-mediator variable distinction in social psychological research. J. Personal. Soc. Psychol. 1987, 51, 1173-1182. [CrossRef]

73. Mackinnon, D.P. Introduction to Statistical Mediation Analysis; Lawrence Erlbaum Associates: London, UK, 2008. 